\title{
PENATAAN PERUMAHAN KUMUH DI PERKOTAAN BERBASIS KAWASAN
}

\author{
Noegi Noegroho \\ Jurusan Arsitektur, Fakultas Sains dan Teknologi, Bina Nusantara University \\ Jln. KH Syahdan No 9, Palmerah, Jakarta Barat 11480
}

\begin{abstract}
Cities in Indonesia has the same problem in the presence of slum residential in some area. The existence keeps growing altogether with the increasing of population and urbanisation in some cities. Slum residential brings several bad effects towards urban life, not only based on physical performance but also affects the decreasing in human resource quality especially those who live in the area. Along with the city development, slum residential should be arranged into a livable environment; which could be handled by area-based that placed the slum area arranged altogether by supervising surrounded environment like a united area.
\end{abstract}

Keywords: residential, slum area, re-arrenged

\begin{abstract}
ABSTRAK
Kota-kota di Indonesia memiliki permasalahan sama dengan hadirnya perumahan kumuh di bagian wilayahnya. Keberadaannya terus tumbuh berbarengan dengan meningkatnya jumlah penduduk dan urbanisasi yang melanda umumnya kota-kota tersebut. Perumahan kumuh membawa berbagai macam dampak buruk terhadap kehidupan kota tidak saja dari sisi fisik kota namun juga mengakibatkan menurunnya kualitas sumber daya manusia khususnya yang tinggal di lingkungan tersebut. Sejalan dengan perkembangan kota, perumahan kumuh in tentu harus ditata menjadi lingkungan yang layak huni, salah satunya adalah penanganan berbasis kawasan yang menempatkan lingkungan kumuh ini ditata secara berbarengan dengan memperhatikan lingkungan sekitarnya seperti sebuah kawasan kesatuan.
\end{abstract}

Kata kunci: perumahan, kawasan kumuh, penataan ulang 


\section{PENDAHULUAN}

\section{Latar Belakang}

Berdasarkan sensus penduduk yang diadakan pada tahun 2010, jumlah penduduk Indonesia saat ini berjumlah sekitar 210 juta jiwa, suatu jumlah yang cukup besar. Hampir 50\% penduduk tersebut tinggal di kawasan perkotaan. Pesatnya pertumbuhan penduduk di kawasan perkotaan ini sering mengalahkan kemampuan kota dalam penyediaan pelayanannya termasuk infrastruktur dan penyediaan pemukiman yang layak bagi warganya, akibatnya muncul banyak lingkungan perumahan kumuh. Pada tahun 2004, luas pemukiman kumuh mencapai 54.000 ha, luas ini terus berkembang hingga 59.000 ha pada tahun 2009 (Laporan Pendahuluan PLP2K-BK, 2010).

Meluasnya lingkungan permukiman kumuh diperkotaan membawa banyak konsekwensi pada kehidupan di perkotaan. Secara estetika, konsekwensi nya adalah menimbulkan lingkungan yang rendah kualitasnya. Namun lebih dari itu, pemukiman kumuh ini mengakibatkan konflik ruang, kawasan hunian yang sesak dengan daya dukung rendah, menurunnya tingkat kesehatan masyarakat, menurunnya kualitas pelayanan prasarana dan sarana permukiman. Belum lagi karena kepadatannya, dapat meningkatkan kerawanan dan konflik sosial. Oleh karena itu, permukiman kumuh di perkotaan ini harus segera ditangani agar dampak buruk tidak semakin bertambah.

Banyak pemerintah daerah (pemkot) di kota-kota Indonesia sudah menangani pemukiman kumuh dengan berbagai macam cara, tentu disesuaikan dengan kondisi masing-masing daerah yang bersangkutan. Salah satu model penanganan lingkungan kumuh ini adalah penataan berbasis kawasan yang mengintegrasikan pemukiman kumuh ini dengan lingkungan sekitarnya sebagai satu kawasan, artinya mengintegrasikan dengan kegiatan lingkungan di sekitarnya (sistem kota) baik aktivitas ekonomi, lingkungan fisik, maupun lingkungan sosial. Dengan perencanaan model ini, diharapkan kawasan kumuh akan berkembang secara berkelanjutan dan saling mendukung dengan potensi-potensi perkembangan yang ada disekitarnya.

\section{Kebutuhan Rumah dan Peraturan yang Mendasari Pengembangan Kawasan Perumahan dan Permukiman}

Dari waktu ke waktu, rumah semakin dibutuhkan oleh setiap rumah tangga bersamaan dengan kebutuhan pokok sandang dan pangan. Kebutuhan rumah tidak saja dilihat dari aspek kuantitasnya saja namun juga kualitasnya. Kebutuhan rumah ini semakin bertambah sejalan dengan bertambahnya kawasan perkotaan di berbagai wilayah di Indonesia. UUD 1945, Pasal 28H ayat (1) menyatakan bahwa "Setiap orang berhak hidup sejahtera lahir dan batin, bertempat tinggal, dan mendapatkan lingkungan hidup yang baik dan sehat serta berhak memperoleh pelayanan kesehatan". Amanat UUD 1945 tersebut memposisikan bahwa rumah atau tempat tinggal sebagai hak setiap orang. Rumah merupakan kebutuhan dasar manusia dalam meningkatkan harkat, martabat, kualitas kehidupan, serta sebagai cerminan diri. Lebih dari itu rumah juga berperan dalam pembentukan watak, karakter dan kepribadian bangsa.

Berdasarkan hasil Survei Sosial Ekonomi Nasional 2004, dari 55 juta keluarga di Indonesia, sekitar 5,9 juta di antaranya belum memiliki rumah. Sementara itu, setiap tahun terjadi penambahan kebutuhan rumah dari keluarga baru sekitar 820.000 unit rumah. Selain itu, masih terdapat 3,1 juta keluarga atau 12,5 juta jiwa keluarga yang menghuni rumah dalam kondisi yang tidak Iayak. Angkaangka ini menunjukan besarnya kebutuhan rumah namun belum terpenuhi.

Pemerintah sudah berupaya memenuhi kebutuhan rumah bagi warganya sejak Pelita 1 hingga sekarang. Untuk mengejar ketertinggalan pemenuhan akan rumah, Kementerian Negara Perumahan 
Rakyat telah menetapkan beberapa sasaran di bidang perumahan dalam Rencana Strategis (Renstra) Kementerian Negara Perumahan Rakyat 2004-2009, yang meliputi: (1) penyediaan prasarana dan sarana dasar bagi kawasan RS dan RsH; (2) pengembangan kawasan perumahan dan permukiman seluas 10.000 ha; (3) pengembangan pola subsidi yang tepat sasaran, efisien dan efektif sebagai pengganti subsidi selisih bunga; (4) penyediaan 1.350 .000 unit rumah baru layak huni bagi masyarakat yang belum memiliki rumah; (5) peningkatan akses masyarakat kepada kredit mikro (small scale credit) untuk pembangunan dan perbaikan rumah yang berbasis swadaya masyarakat sebanyak 3.600.000 unit rumah; (6) pembangunan 60.000 unit rusunawa bagi MBR; (7) pembangunan 25.000 unit rusunami melalui peran serta swasta.

Namun karena jumlah kebutuhan akan rumah yang sangat besar, maka pemenuhan akan rumah belum terkejar hingga saat ini, belum lagi dalam pelaksanaannya ditemukan berbagai macam hambatan. Hambatan utama adalah semakin langkanya lahan bagi pengembangan kawasan perumahan di perkotaan, kalaupun ada tentu harganya sangat mahal dan menjadi tidak efisien untuk dibangun sebagai perumahan murah bagi golongan Masyarakat Berpenghasilan Rendah (MBR). Berkaitan dengan penataan perumahan di perkotaan khususnya perumahan kumuh, hambatan yang dijumpai adalah penanganan yang masih cenderung parsial dan belum efektif dan masih luasnya kawasan perumahan yang berkembang kurang terintegrasi dan serasi dengan fungsi kawasan di sekitarnya.

Lebih jauh dari itu, menurut Adisasmita (2010) mengatakan bahwa Pembangunan lingkungan perumahan merupakan bagian dari perencanaan pembangunan daerah-daerah tempat tinggal dalam suatu daerah perkotaan, untuk membangun kesatuan masyarakat kecil dalam jumlah banyak yang dilengkapi dengan sarana/fasilitas pelayanan kebutuhannya. Dalam pengembangan perumahan, ada beberapa peraturan dan perundangan yang mendasarinya, antara lain:

\section{UU No.4 Tahun 1992 tentang Perumahan dan Permukiman}

Perumahan dan permukiman yang layak, sehat, aman, serasi, dan teratur merupakan salah satu kebutuhan dasar manusia dan merupakan faktor penting dalam peningkatan harkat dan martabat mutu kehidupan serta kesejahteraan rakyat. Setiap warga negara mempunyai hak untuk menempati dan/atau menikmati dan/atau memiliki rumah yang layak dalam lingkungan yang sehat, aman, serasi, dan teratur. Setiap warga negara juga wajib berperan serta dalam pembangunan perumahan dan permukiman. Oleh karena itu, pembangunan perumahan dan permukiman perlu terus ditingkatkan dan dikembangkan secara terpadu, terarah, berencana, dan berkesinambungan.

Dalam UU no. 4 ini, perumahan diartikan sebagai kelompok rumah yang berfungsi sebagai lingkungan tempat tinggal atau lingkungan hunian yang dilengkapi dengan prasarana dan sarana lingkungan (suparno, 2006). Dalam UU ini juga disampaikan bahwa penataan perumahan dan permukiman perlu dilakukan dalam rangka: (1) memenuhi kebutuhan rumah sebagai salah satu kebutuhan dasar manusia, dalam rangka peningkatan dan pemerataan kesejahteraan rakyat; (2) mewujudkan perumahan dan permukiman yang layak dalam lingkungan yang sehat, aman, serasi, dan teratur; (3) memberi arah pada pertumbuhan wilayah dan persebaran penduduk yang rasional; (4) menunjang pembangunan di bidang ekonomi, sosial, budaya, dan bidang-bidang lain.

Oleh karena itu, pembangunan perumahan dan permukiman harus diselenggarakan berdasarkan rencana tata ruang wilayah perkotaan dan rencana tata ruang wilayah, yang menyeluruh dan terpadu, yang ditetapkan oleh pemerintah daerah dengan mempertimbangkan berbagai aspek yang terkait dengan rencana, program, dan prioritas pembangunan perumahan dan permukiman.

Dalam UU ini juga diatur mengenai peran serta masyarakat dalam pengembangan kawasan perumahan dan permukiman. UU ini menjamin hak dan kesempatan yang sama dan seluas-luasnya bagi setiap anggota masyarakat untuk berperan serta dalam pembangunan perumahan dan permukiman, baik secara perseorangan atau dalam bentuk usaha bersama. 


\section{Permenpera No.34/Permen/M/2006 Tentang Pedoman Umum Penyelenggaraan Keterpaduan Prasarana, Sarana, dan Utilitas (PSU) Kawasan Perumahan}

Penyediaan Prasarana, Sarana dan Utilitas Umum (PSU) perumahan dan permukiman merupakan kelengkapan dasar fisik lingkungan, fasilitas penunjang dan sarana penunjang untuk pelayanan lingkungan dan atau kawasan perumahan dan menjadi bagian yang tidak terpisahkan dalam pembangunan perumahan secara keseluruhan. Oleh karena itu, penyediaan rumah layak huni yang sehat, aman, serasi, teratur dan berkelanjutan perlu didukung dengan penyediaan Prasarana, Sarana dan Utilitas Perumahan dan Permukiman.

Penanganan keterpaduan PSU kawasan dilakukan melalui: (1) Pembangunan kawasan perumahan dan permukiman skala besar yang terencana secara menyeluruh dan terpadu dengan pelaksanaan yang dapat dilaksanakan secara bertahap; (2) Pembangunan kawasan khusus, yaitu pada bagian wilayah dalam propinsi dan/atau Kabupaten/Kota untuk menyelenggarakan kegiatan dengan fungsi khusus seperti industri, perbatasan, nelayan, pertambangan, pertanian, pariwisata, pelabuhan, cagar budaya, dan rawan bencana; (3) Peningkatan kualitas permukiman berupa kegiatan pemugaran, perbaikan dan peremajaan dan mitigasi bencana. Adapun komponen PSU Kawasan yang diatur keterpaduannya yaitu: jalan, drainage, air limbah, limbah padat (sampah), jaringan air minum, tempat pendidikan, fasilitas kesehatan, fasilitas perdagangan, fasos dan fasum, tempat olah raga, pemakaman, ruang terbuka hijau, terminal, jaringan listrik, telepon, gas, tranportasi dan pemadam kebakaran.

\section{Permenpera No.11/Permen/M/2008 tentang Pedoman Keserasian Kawasan Perumahan dan Permukiman}

Dalam rangka mewujudkan kawasan perumahan dan permukiman yang serasi, diperlukan suatu kebijakan yang mengatur keserasian kawasan sehingga kawasan perumahan dan permukiman dapat tertata dengan baik, manusiawi, serta menjamin tatanan kehidupan yang berkelanjutan.

Penyusunan pedoman ini pada dasarnya bertujuan untuk: (1) terwujudnya kawasan perumahan dan permukiman yang tertata dengan baik yang dapat menunjang peningkatan kualitas ekologis, pertumbuhan ekonomi, dan pembangunan sosial budaya, serta menjamin tatanan kehidupan yang berkelanjutan; (2) tersedianya acuan bagi pemerintah daerah dalam menyusun kebijakan, badan usaha dan masyarakat dalam pelaksanaan pembangunan kawasan perumahan dan permukiman melalui penyelenggaraan keserasian kawasan; (3) terdorongnya pemerintah daerah, badan usaha, badan sosial, dan keagamaan, serta masyarakat, untuk mewujudkan keserasian kawasan perumahan dan permukiman.

\section{Penanganan Kawasan Pemukiman Kumuh di Perkotaan}

Penangan Kawasan Pemukiman kumuh di perkotaan yang berbasis kawasan harus dilandasi oleh karakteristik lahan dan sekitarnya. Hal ini akan menentukan konsep, strategi dan bentuk penangannya. Dalam penanganannya ada beberapa pertimbangan utama antara lain masalah status tanah, perkembangan kawasan dan dinamikanya, dan peran serta masyarakat.

\section{Status tanah}

Masalah status tanah adalah faktor pertimbangan utama dalam menangani pemukiman kumuh di perkotaan. Penanganan kawasan kumuh dengan status tanah negara akan berbeda dengan kawasan kumuh dengan status tanah hak milik. Pada status tanah negara harus dimulai dengan aspek penegasan status tanah terlebih. Tahap ini sering menimbulkan konflik jika tidak disosialisasikan dengan baik. Berbeda dengan penanganan pada perumahan kumuh dengan status tanah yang sudah hak milik, penanganannya dimulai kesepakatan terlebih dahulu dengan pemilik tanah. Tanpa kesepakatan dengan pemilik tanah maka rencana yang sempurna sekalipun akan sulit direalisasikan. 
Melihat sangat pentingnya status tanah, secara umum tipologi penanganan kawasan permukiman dapat dibedakan berdasarkan status kepemilikan tanahnya, yaitu: (1) kawasan dengan dominasi tanah negara; (2) kawasan dengan dominasi tanah milik, lebih dari itu, yang juga mempengaruhi cara penanganan kawasan kumuh adalah aspek ekonomi dan lokasi; (3) kawasan dengan nilai ekonomi tinggi misalnya berada di tengah kota; (4) kawasan dengan nilai ekonomi rendah, misalnya berada di pinggiran kota atau daerah banjir.

Dari uraian diatas, status kepemilikan tanah dan nilai ekonomi kawasan jelas akan membedakan cara penanganan, khususnya yang terkait dengan aspek pendanaan, sifat kelembagaan dan stakeholder yang terlibat dalam penangannnya. Berdasarkan hal tersebut maka strategi penanganan dapat dikelompokan menjadi 3 bagian yaitu konsep pengembangan fisik kawasan, konsep pengembangan ekonomi kawasan, dan konsep pengembangan kelembagaan.

Konsep pengembangan fisik dan ekonomi kawasan merupakan upaya untuk meningkatkan kualitas ruang didalam kawasan melalui rekayasa fisik. Hal ini untuk mendorong perkembangan potensi ekonomi yang terdapat didalam kawasan baik melalui pengembangan kegiatan yang sudah berkembang maupun pengembangan kegiatan kegiatan ekonomi baru. Sedangkan pengembangan kelembagaan diperlukan sebagai manajemen yang akan mengelola kawasan perencanaan sehingga dicapai pembangunan yang berkelanjutan.

Sebagaimana tercantum dalam Laporan Pendahuluan PLP2K-BK (2010), secara umum parameter dan aspek yang perlu dipertimbangkan dan diasumsikan dalam kajian teknis analisis dalam penanganan kawasan kumuh diperlihatkan pada gambar skematik berikut ini.

\section{PENANGANAN KAWASAN PERMUKIMAN PERKOTAAN} EXISTING

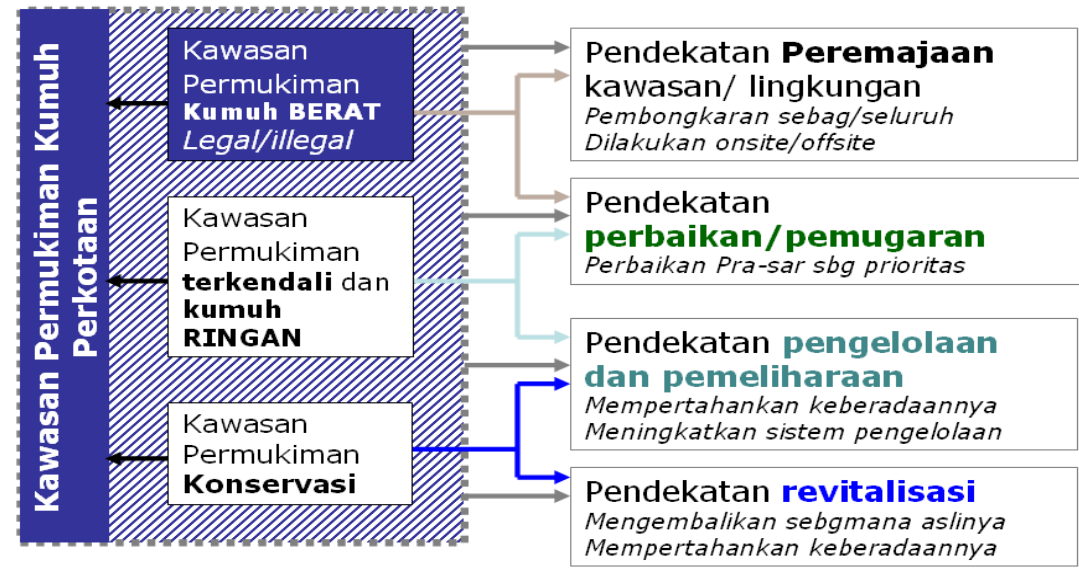

Gambar 1 Gambar skematik kajian teknis analisis penanganan kawasan kumuh̄

Berkaitan dengan peningkatan kualitas fisik ruang kawasan, secara umum dapat dikategorikan menjadi 3 yaitu: (1) peningkatan kualitas fungsional ruang, konsep peningkatan kualitas fungsional adalah untuk meningkatkan fungsi fungsi yang berkembang didalam kawasan perencanaan. Diharapkan dengan meningkatkan fungsi fungsi ruang tersebut akan mendorong perkembangan ekonomi kota. Hal ini dilakukan dengan penataan ruang baik organisasi ruang, hubungan ruang maupun intensitas ruang; (2) peningkatan kualitas visual ruang kawasan, konsep peningkatan kualitas visual ruang kawsan dilakukan untuk meningkatkan mutu visual kawasan sehingga kawasan dapat lebih menarik untuk di kunjungi maupun di tinggali. Upaya untuk meningkatkan kualitas visual ini antara lain dilakukan dengan penataan tata bangunan, tata informasi, ruang terbuka dan tata hijau, pembentukan image kota, dan sebagainya; (3) peningkatan kualitas lingkungan kawasan, konsep 
peningkatan kualitas lingkungan fisik adalah menciptakan kenyamanan lingkungan dengan penyediaan sistem utilitas lingkungan yang memadai . Sedangkan lingkungan sosial budaya adalah menciptakan iklim yang kondusif bagi masyarakat untuk berperan secara aktif dalam pembangunan dan menikmati pembangunan di kawasan perencanaan.

\section{Perkembangan Kota dan Dinamika Kawasan}

Perkembangan kota dan kawasan di sekitar perumahan kumuh yang akan ditata tidak lepas dari pertimbangan dalam penataan. Pertimbangan meliputi: (1) tingkat dinamika perkembangan kota , khususnya wilayah di sekitar kawasan penataan antara lain sosial ekonomi penduduk dan aktivitas kegiatannya; (2) mobilitas pergerakan masyarakat di kawasan sekitar; (3) kepastian hukum dengan melibatkan pihak swasta dan masyarakat, tidak hanya meliputi rencana teknis/desain penataan bangunan saja, namun menyangkut pula institusi pengelolaanya; (4) sinergi dan keseimbangan antara zona-sona aktivitas 'bangkitan' kehidupan sosial ekonomi di dalam kawasan perencanaan berdasarkan prinsip-prinsip peremajaan dan peningkatan kawasan. Pertimbangan ini menghasilkan konsep pengembangan segmen ruang kawasan; (5) kendala keterbatasan lahan dengan konsep mengoptimalkan intensitas ruang, antara lain dengan: pengembangan kawasan secara vertikal pada beberapa bagian untuk menghindari kepadatan bangunan yang berlebihan, memperpanjang waktu aktivitas pada sebuah ruang yang sama, dan menggunakan ruang bebas bangunan di tepi jalan utama dan sungai sebagai ruang ekonomi yang disesuaikan dengan peraturan; (6) pembentukan pola bangunan yang mendukung pengembangan arsitektur kota; (7) meningkatkan keragaman kegiatan yang saling mendukung didalam kawasan perencanaan, antara lain dengan menciptakan ruang yang terorganisasi untuk aktivitas beragam namun berkarakter sama yang saling terkait secara fungsional misalnya aktivitas perdagangan dengan jasa, ruang terbuka dengan hunian , transportasi dengan pelayanan umum, mengelompokan kegiatan tersebut dalam satu segmen penataan kawasan perencanaan, dan menghubungkan (linkage) antar kegiatan di dalam kawasan perencanaan dengan di luar kawasan, maupun yang menghubungkan antar segmen kegiatan didalam kawasan; (8) meningkatkan ruang terbuka hijau untuk keseimbangan ruang terbangun dan ruang terbuka di dalam kawasan. Secara fungsional, ruang terbuka di kawasan dapat dibedakan atas ruang terbuka umum (public domain) dan ruang terbuka private (private domain). Sedangkan secara visual, ruang terbuka yang ada dapat dibedakan atas ruang terbuka taman, dan koridor atau jalur. Peningkatan ruang terbuka ini agar: meningkatkan kualitas visual ruang-ruang terbuka yang sudah ada, khususnya ruang terbuka umum seperti jalur pedestrian, dan jalur hijau, mengembangkan ruang-ruang terbuka baru, baik dalam bentuk taman, maupun koridor / jalur dalam rangka mengimbangi tingginya intensitas pemanfaatan lahan di dalam kawasan, memadukan ruang-ruang terbuka umum dan ruang terbuka private yang secara kolektif dapat memenuhi kebutuhan ruang terbuka kawasan, dan meningkatkan partisipasi aktif masyarakat dalam penyediaan ruang terbuka kawasan; (9) meningkatkan potensi ekonomi ruang kawasan, meliputi: peningkatan kualitas fungsi permukiman, peningkatan prasarana dasar seperti jalan dan transportasi, ketersediaan supply jaringan air bersih, drainase, jaringan pengolahan air limbah baik on-site system maupun off-site system, dan pengolahan persampahan serta prasrana pendukung seperti ketersediaan jaringan listrik, dan telekomunkasi, peningkatan kualitas fungsi sosial dan budaya, berupa alokasi ruang-ruang sebagai wadah kegiatan sosial dan budaya masyarakat seperti penyediaan ruang bersama, pertemuan, rekreasi, taman, olahraga tempat tempat aktivitas umum lainnya, dan peningkatan kualitas fungsi ekonomi: formal dan informal berupa alokasi ruang-ruang kota untuk mendukung perkembangan dan pertumbuhan sektor ekonomi.

\section{Peran Serta Masyarakat}

Dalam penanganan kawasan pemukiman kumuh, satu hal yang tidak bisa ditinggalkan adalah peran serta masyarakat baik itu masyarakat yang ditata maupun pihak lain yang berkepentingan terhadap kawasan tersebut. Mengacu pada Laporan Pendahuluan pekerjaan PLP2K-BK (2010), penataan kawasan kumuh tidak saja mengacu kepada aspek legal namun juga harus mempertimbangkan beberapa aspek lain yaitu: (1) azas demokratis, semua yang akan dilakukan 
berdasar atas kehendak dan kesepakatan bersama (CBD); (2) azas partisipatif, penggalangan aspirasi dan peran dari seluruh lapisan masyarakat secara aktif; (3) azas keberlanjutan, dalam pemahaman ini lebih ditekankan adanya keterdukungan (sustenance), yaitu kecukupan pasokan sumber daya yang mendukung kehidupan lingkungan permukiman; (4) azas pemberdayaan masyarakat, pengelolaan pemukiman menjadi alat untuk mencapai tujuan termasuk keterlibatan total masyarakat untuk mengelola sendiri lingkungan permukimannya (people centered management).

Berkaitan dengan peran serta masyarakat, harus dilakukan konsolidasi para stake holder terkait untuk mengefektifkan dan mengkoordinasikan pelaksanaan kegiatan. Konsolidasi ini direalisasikan dengan membentuk forum komunikasi yang beranggotakan unsur-unsur Pemerintah Kabupaten/Kota dan masyarakat/swasta. Forum akan mewakili seluruh pelaku pembangunan (stakeholders) yang terlibat dalam kegiatan pembangunan permukiman, LSM, kelompok warga, sektor swasta. Forum komunikasi ini bermanfaat untuk mempetemukan berbagai macam kepentingan dalam sebuah wadah kerjasama. Lebih jauh, forum ini dapat berfungsi antara lain: (1) mengkoordinasikan semua kegiatan pembangunan perumahan dan permukiman yang dilaksanakan; (2) menampung aspirasi masyarakat serta menjaring aspirasi-aspirasi tersebut untuk disalurkan ke Pemerintah Kabupaten/Kota dan Pusat; (3) menjembatani kepentingan masyarakat dengan pihak lain yang terlibat (baik pemerintah maupun non pemerintah); (4) merumuskan kesepakatan mengenai pengaturan wewenang dan tanggung jawab; (5) mempromosikan pentingnya peningkatan kesadaran serta memperdalam rasa ikut memiliki dalam pengelolaan asset perumahan dan permukiman; (6) mengawasi pelaksanaan pembangunan; (7) mengidentifikasi kemungkinan terjadinya perubahanperubahan yang dapat mengubah kesesuaian peruntukan lahan yang sudah dialokasikan dalam perencanaan tata ruang secara integrasi; (8) mengidentifikasi masalah-masalah yang ada dan mengusulkan solusi untuk dipertimbangkan Pemerintah Kabupaten/Kota.

\section{SIMPULAN}

Rumah merupakan kebutuhan dasar yang harus terpenuhi oleh setiap warga negara sesuai amanat UUD 45 Republik Indonesia, namun karena keterbatasan pemerintah hingga saat ini masih banyak masyarakat yang belum memiliki rumah. Masyarakat mencari cara sendiri untuk memiliki rumah, antara lain dengan mendirikan rumah seadanya di kawasan perkotaan. Rumah tanpa fasilitas sekedar tempat berlindung dari panas dan hujan dikenal dengan perumahan kumuh. Banyak konsekwensi yang ditimbulkan oleh hadirnya perumahan kumuh ini, mulai dari rendahnya kualitas sumber daya manusia yang tinggal di lingkungan ini, kerawanan sosial dan kriminal hingga rendahnya estetika kota. Sejalan dengan pertumbuhan penduduk perkotaan yang cenderung meningkat maka kawasan kumuh perkotaan ini juga meningkat. Dalam kurun waktu 5 tahun (2004 -2009) kawasan kumuh di Indonesia bertambah dari 54.000 ha menjadi 59.000 ha.

Banyak pemerintah daerah/kota di Indonesia memutar otak untuk mengurangi jumlah perumahan kumuh di daerahnya masing-masing. Beragam program sudah digulirkan untuk memecahkan masalah ini (mis : program NUSSP surabaya, Program MHT di Jakarta). Salah satu model adala penataan kawasan kumuh dengan perencanaan berbasis kawasan. Penataan lingkungan kumuh dengan 'menyatukan'nya pada lingkungan sekitarnya menjadi satu kesatuan sehingga perkembangannya pun kemudian menjadi saling terkait dengan lingkungan yang lebih luas. Namun sebelum program dimulai, pemahaman karakteristik lahan dan kawasan mutlak diketahui karena akan menentukan cara penanganannya. Ada beberapa hal yang menjadi dasar yaitu : status tanah, perkembangan kota dan peran serta masyarakat. Semua ini yang harus jelas terlebih dahulu agar pelaksanaan penataan tersebut tidak mengalami kendala sehingga harapan untuk menciptakan lingkungan hunian yang nyaman dan aman dapat terwujud. 


\section{DAFTAR PUSTAKA}

Adisasmita. R. (2010). Pembangunan Kawasan dan Tata Ruang (1st ed.). Yogyakarta: Graha Ilmu.

Sastra, S. (2006). Perencanaan dan Pengembangan Perumahan. Yogyakarta: CV. Andi Offset.

Gandarum, D. N. (2008). Prinsip-Prinsip Pengembangan Permukiman Baru Tinjauan Arsitektur Kota. Jakarta: Penerbit Universitas Trisakti.

Laporan Pendahuluan PLP2K-BK Medan. (2010). Jakarta: PT. Patita. 